\title{
Probability of Heavy Metals Mobility from Dumped Sediments in a Quarry
}

\author{
García-Rangel, Karina T. ${ }^{1}$; Gavi-Reyes Francisco ${ }^{1}$; Garrillo-González Rogelio ${ }^{2 *}$; \\ Martínez-Menes, Mario ${ }^{1}$ \\ 1 Programa de Hidrociencias. Colegio de Postgraduados. Texcoco, México, México, C. P. 56230. \\ 2 Programa de Edafología. Colegio de Postgraduados. Texcoco, México, México, C. P. 56230 \\ * Corresponding author: crogelio@colpos.mx
}

Citation: García-Rangel, Karina T.; Gavi-Reyes Francisco; CarrilloGonzález, Rogelio; Martínez-Menes, Mario. (2021). Probability of Heavy Metals Mobility from Dumped Sediments in a Quarry. Agro Productividad. https://doi.org/10.32854/ agrop.v14i8.1952

Editor in Chief: Dr. Jorge Cadena Iñiguez

Received: February, 2021 Accepted: August, 2021.

Estimated publication date: September, 2021

This work is licensed under a Creative Commons Attribution-NonCommercial 4.0 International license.

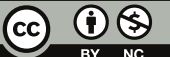

\begin{abstract}
Dregs from the former Texcoco Lake were used to build the new international Mexico City airport and pumped in a quarry. The dredged sediments could have heavy metals (HMs) capable of polluting water bodies. The study's objective was to evaluate the content of $\mathrm{Cu}, \mathrm{Zn}, \mathrm{Cd}, \mathrm{Ni}$, and $\mathrm{Pb}$ of the sediments deposited in the quarry, their transfer to the runoff water and the adsorption of $\mathrm{Cu}, \mathrm{Zn}, \mathrm{Ni}$, and $\mathrm{Pb}$ in the subsoil. Other variables measured were water infiltration rate, HM in sediments, water runoff, and the $\mathrm{HM}$ adsorption in the subsoil. The infiltration rate in sediments is low $(\leq 10-7 \mathrm{~cm} / \mathrm{h})$. HMs in sediments are within the maximum permissible limits by Mexican regulations, for sewage sludge. The HMs in the runoff from the sediments are in the range of the Mexican regulations for the discharge into rivers and for irrigation purposes of agricultural soils. They are also within safe limits for irrigation use considered by FAO and EPA. The materials adsorption capacity of $\mathrm{Pb}\left(1250 \mathrm{mg} \mathrm{kg}^{-1}\right), \mathrm{Zn}\left(588 \mathrm{mg} \mathrm{kg}^{-1}\right)$, and $\mathrm{Cu}(1250 \mathrm{mg}$ $\mathrm{kg}^{-1}$ ) is higher than the concentration of metals in the runoff water, so the movement of HMs down into the subsoil is unlikely.
\end{abstract}

\section{INTRODUGTION}

Mining of materials for construction in open-pit mines is relatively inexpensive, but it causes conspicuous changes in ecosystems. Among its negative effects there is deforestation, habitat destruction, landscape change, rock fracturing from the use of explosives, dust generation, alteration of the site's hydrology, formation of large craters with risk of collapse (Green et al., 2005, Korkmaz et al., 2011).

Performing large civil works involves the removal of the superficial layer of the soil or unstable sediments for the foundation of the structures. For the construction of the new international airport in Mexico City (NAICM, the acronym in Spanish language) in the former Texcoco Lake, it was necessary to drag and transport large volumes of sediment to authorized confinements (GACM, 2014). The confinements are located $10 \mathrm{~km}$ away in the middle part of the Sierra Nevada that fed the lake. Due to the origin and management 
of the excavation material, the place of its confinement and the concentrated volume, the following question arises: Could the sediments represent a source of heavy metals (HMs) that would contaminate the bodies of water that are used for human consumption and other activities such as agriculture? The confinement site corresponds to an exhausted quarry, adjacent to a tributary of the Texcoco River, of up to $65 \mathrm{~m}$ of depth, abandoned without rehabilitation. The appropriate use of these sinkholes as confinement sites could solve two environmental problems of strong impact in the zone, the rehabilitation of the quarry and the confinement of sediments, but could unleash a greater impact in the long term: underground water contamination.

The sediment from the former lake constitutes the superior clay formation (Anónimo, 2014). It has a very alkaline $\mathrm{pH}$ (Balderas et al., 2006), deficient drainage, high content of salts and high rate of exchangeable sodium (Segura et al., 2000). This sediment contains $\mathrm{Ni}, \mathrm{Cu}, \mathrm{Mo}, \mathrm{Pb}$ (Morales-García et al., 2020), Cr, Zn and V (Morton-Bermea et al., 2009), whose origin is a combination of the open air conditions of the rock from the high parts of the basin, industrial activities and flow transport, among the most notable sources. The Fe, $\mathrm{Pb}, \mathrm{Cr}, \mathrm{As}, \mathrm{Cu}, \mathrm{Zn}, \mathrm{Cd}, \mathrm{V}$, and $\mathrm{Hg}$ content was reported in sediments from other lakes (Vowotor et al., 2014; Pejman et al., 2015). The metals can be freed as a result of different processes, among them their physical alteration, which can increase their solubility and impact negatively the environment (Wu et al., 2014). Vowotor et al. (2014) suggest the following potential for ecological risk: $\mathrm{Cd}>\mathrm{Hg}>\mathrm{As}>\mathrm{Pb}>\mathrm{Cu}>$ $\mathrm{Cr}>\mathrm{Zn}$.

The HMs of the sediment have low or null potential for lixiviation because they are united to stable mineral fractions in the soil (Balderas et al., 2006). In an alkaline medium the mobility of metals is minimized, and this sediment has poor drainage, characteristic derived from its high content of smectites (Ortiz and Gutiérrez, 2015) and amorphous silica (Balderas et al., 2006), as well as the lack of structure due to its high sodium content (Rowell, 1994).

In the confinement site, the impermeability of the bottom would favor rainfall runoff and cracking could give rise to a preferential flow of HMs towards water table layers, although it is unknown whether the site has cracks formed during the material's extraction. And, depending on its ability to sorb metals, it could continue its migration towards underground waters, since the potential of transference of HM contents in the sediments towards the water medium depends on their concentration and solubility (Kabata-Pendias, 2011).

Soluble HMs in the infiltration water can be adsorbed in the bottom of the confinement (Van der Perk, 2013) and with it, reduce the risk of contamination of underground waters. The adsorption in the soil-water interphase (Sparks, 2003) indicates the capacity of substrates to retain solutes (Appelo and Postma 2005), with which their mobility can be predicted. The best known models to simulate the isotherms are those by Freundlich and Langmuir (Roy et al., 1992). The objective of this study was to evaluate the content of Cu, $\mathrm{Zn}, \mathrm{Cd}, \mathrm{Ni}$ and $\mathrm{Pb}$ of the sediments of the former Texcoco Lake and in the runoff water, and the sorption of $\mathrm{Cu}, \mathrm{Zn}, \mathrm{Ni}$ and $\mathrm{Pb}$ in the bottom of the confinement. 


\section{MATERIALS AND METHODS}

\section{Localization and Delimitation of the Confinement of Sediments}

The site for confinement of the sediments is known as Tiro San Dieguito and it is located in San Dieguito Xochimanca, Texcoco, Mexico at $19^{\circ} 29^{\prime} 53.08^{\prime \prime} \mathrm{N}$ and $98^{\circ} 49^{\prime} 42.36^{\prime \prime}$ $\mathrm{W}$ of latitude and longitude, respectively (Figure 1). This is a mine quarry of non-metallic rocky material that was abandoned some years ago. It has a surface of 2.49 ha and down to $66 \mathrm{~m}$ in its deepest part. With the help of a total station (Sokkia) and satellite image, the volume of the sediments in the confinement was delimited and obtained, for which the QGis software was used (QGIS Development Team, 2009). The weight of the confined sediment was determined based on its volume and apparent density (Da) obtained by the procedure described by Rowell (1994).

\section{Permeability Test in the Sediments}

Permeability (as infiltration speed) was measured using the procedure proposed by Siltecho et al. (2015). Waterproof PVC tubes were used $(5 \mathrm{~cm}$ of diameter by $40 \mathrm{~cm}$ of length), to obtain unaltered samples in the bottom of the quarry (Figure 1b), $30 \mathrm{~cm}$ deep; $2 \mathrm{~L}$ of rain water was added to measure the infiltration at 24 and 48 hours.

\section{Sampling and $\mathrm{Cd}, \mathrm{Cu}, \mathrm{Zn}, \mathrm{Ni}$ and $\mathrm{Pb}$ analyses in the Sediments}

Through random sampling of the confinement area (2.49 ha), 19 samples $(2 \mathrm{~kg})$ of sediment were collected from the superficial layer of $0-20 \mathrm{~cm}$. The samples were dried at $35^{\circ} \mathrm{C}$ for $72 \mathrm{~h}$ and sifted in a size 10 sieve $(2 \mathrm{~mm})$ according to the NMX-AA-132SCFI-2006 (SE, 2017). The HMs were determined through digestion of the sample with nitric acid according to the NOM-004-SEMARNAT-2002 (SEMARNAT, 2003) and reading was made in an inductively coupled plasma spectrophotometer (ICP-OES) Varian 725-ES model (Agilent Technologies, 2012).
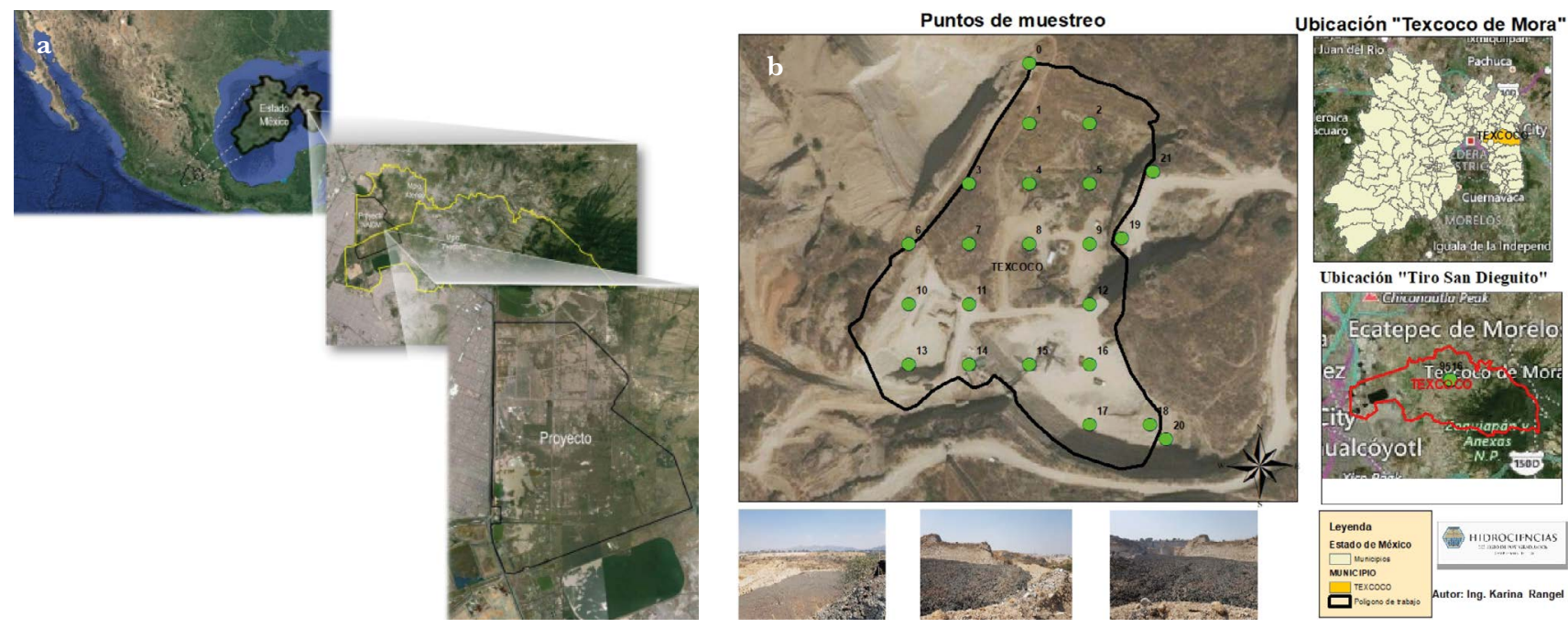

Figure 1. a) Location of the NIAMC (SCT, 2014) and b) sampling points on the quarry used as disposal area. 


\section{Sample and $\mathrm{Cd}, \mathrm{Cu}, \mathrm{Zn}, \mathrm{Ni}$ and $\mathrm{Pb}$ analyses in Runoff Water}

The runoff water of the sediment was sampled in the quarry during the rainfall period (May to August 2018). After each rainfall, simple samples from the surface of the sediment were obtained in the zones flooded, and with these a compound sample was obtained according to the NMX-AA-003-1980 (SECOFI, 1980). The pH was determined from the samples potentiometrically (Rowell, 1994). Later, they were acidified $(\mathrm{pH}<2)$ through the addition of nitric acid, kept at $4{ }^{\circ} \mathrm{C}$ and filtered (NMX-AA-051-SCFI-2016; SE, 2016a). The quantification of metals was done with ICP-OES. The $\mathrm{pH}$ and the EC were determined by the procedures described previously.

\section{Sampling and Characterization of the Subsoil of the Quarry}

Previous to removing the sediments, samples were obtained from the subsoil exposed in the mine's sinkhole at a depth of $0-20 \mathrm{~cm}$. The samples were prepared for their characterization according to the NMX-AA-132-SCFI-2006 (SE, 2017), characterized, and the determinations of $\mathrm{Cd}, \mathrm{Cu}, \mathrm{Ni}, \mathrm{Pb}$ and $\mathrm{Zn}$ were made with the procedures described previously. In the sediments and the material from the bottom of the sinkhole, the $\mathrm{pH}$, electric conductivity $(\mathrm{EC})$, capacity for cationic exchange (CGE), sodium adsorption ratio (RSA), apparent density (Da) and texture following the procedures described by Rowell (1994) were measured.

\section{Adsorption of Heavy Metals in the Subsoil}

In balance experiments, the adsorption of HM was estimated (Roy et al. 1992). In reactors of $50 \mathrm{~mL}, 5 \mathrm{~g}$ of subsoil were added with increasing concentrations (50, 100, 200, 500, 1000 and $2000 \mathrm{mg} / \mathrm{L}$ ) of $\mathrm{HM}$ with electrolytic solution of $\mathrm{CaCl}_{2} 0.01 \mathrm{M}$ to maintain the ionic strength, in a 1:4 soil-solution rate. The solutions were prepared with the following salts: $\mathrm{Ni}\left(\mathrm{NO}_{3}\right)_{2}, \mathrm{~Pb}\left(\mathrm{NO}_{3}\right)_{2}, \mathrm{ZnSO}_{4} \cdot 7 \mathrm{H}_{2} \mathrm{O}$ and $\mathrm{CuSO}_{4} \cdot 5 \mathrm{H}_{2} \mathrm{O}$. The isotherms of $\mathrm{Cd}$ were not determined since the concentration of this element in the sediments is very low. The interval of concentrations was chosen in function of the change in the slope of the isotherms, although avoiding for precipitation of the element to take place. The suspension was agitated during $6 \mathrm{~h}$ at $120 \mathrm{rpm}$ at $20^{\circ} \mathrm{C}$, until equilibrium concentration. It was centrifuged at $2200 \mathrm{rpm}$ for $10 \mathrm{~min}$ and the supernatant was filtered with Whatman 42 paper. The equilibrium concentration of $\mathrm{Ni}, \mathrm{Pb}, \mathrm{Zn}$ and $\mathrm{Cu}$ was determined in atomic absorption equipment by the flame technique (SE, 2016a). The $\mathrm{pH}$ was measured during equilibrium. The adsorption isotherms were obtained when graphing adsorption in function of the equilibrium concentration. The adjustment of the Freundlinch and Langmuir equations was evaluated using the linear form of each equation (Jain et al., 2004). The respective constants and isotherms predicted by each equation with the adjustment constants were calculated, to compare with the experimental isotherms.

$$
\text { Freundlich equation } \frac{x}{m}=K_{F} C^{1 / n}
$$

Where: $\frac{x}{m}=$ adsorption per unit of mass. $K_{F}$ is Freundlich's distribution coefficient, $n$ is the correction factor, and $C$ is the equilibrium concentration of the adsorptive. 


$$
\text { Langmuir equation } \frac{x}{m}=\frac{K_{L} M C}{\left(1+K_{L} C\right)}
$$

Where: $\frac{x}{m}=$ adsorption per unit of mass. $K_{L}$ is the constant related with the retention force, $M$ is the maximum adsorption and $C$ is the equilibrium concentration of the adsorptive. To ensure the quality control of the data and the repeatability of the analyses, the experiments and analyses were made by triplicate. Certified standards were used (Purity) for the preparation of calibration curves of the equipment.

\section{RESULTS AND DISGUSSION}

\section{Delimitation of the Confinement of Sediments}

In the quarry, andesitic limestone predominates, which are igneous volcanic rock (tephra) fragments solidified at some point of the volcanic eruption, whose mineral composition is similar to the andesitic rock and size smaller than $4 \mathrm{~mm}$ (SGM, 2002). Until June 2018, $1074960 \mathrm{~m}^{3}$ of sediments had been deposited in the confinement site, corresponding to $1096459 \mathrm{~kg}$ of sediment, taking as reference the average apparent density.

\section{Permeability of the Sediments from the Former Texcoco Lake}

The sediment presented null to extremely low hydraulic conductivity (Hazelthon and Murphy, 2007) during the trial that lasted 48 hours. In determinations made in situ with sediments of the former Texcoco Lake, López et al. (2016) reported very low permeability (of 10-3 to $10-6 \mathrm{~cm} / \mathrm{s}$ ) in the hard layer of the sediment, whose thickness varies from 30 to $32 \mathrm{~m}$. Tarín and Velázquez (1986) found that the hydraulic conductivity is $<0.1 \mathrm{~cm} / \mathrm{h}$, even lower than the one determined in this study. The poor permeability is attributed to the lack of structure (Segura et al., 2000; Carranza, 2018) and the content of smectite, which expands and closes the porous spaces when hydrated (Musso et al., 2017). Therefore, a low probability of metal lixiviation is considered. However, under conditions of cracking, not studied in this study, the transference of metals to greater depths (reaching underground water) would be a potential risk.

\section{Heavy Metals in the Sediment}

Due to the values of $\mathrm{pH}, \mathrm{EC}$ and $\mathrm{SAR}$, the sediment is classified as strongly alkaline, very strongly saline, and with high sodium concentration compared to calcium and magnesium (Hazelton and Murphy, 2007; SEMARNAT, 2003). This is an impediment for the development of many cultivated plant species (Sparks, 2003) and can induce the degradation of the soil per salinization (Table 1).

In contrast to what was reported for other lake areas (Morales-García et al., 2020), and in sediments from other lakes (Luo et al., 2008), the HM concentrations are compared with the limits established in national and international regulations; the HMs of the sediments are within the maximum permissible limits for their use with agricultural, forestry, and soil improvement purposes, which includes their urban use with direct public contact during their application, and were classified as excellent according to 
Table 1. Heavy metals, pH, electrical conductivity (EC), cation exchange capacity (CIC) and sodium adsorption ratio (SAR) in the disposed sediment, and maximum permissible limits in the nation regulation for aquatic life protection in North-America.

\begin{tabular}{|c|c|c|c|c|c|c|c|c|c|}
\hline & Cd & $\mathbf{C u}$ & $\mathbf{N i}$ & $\mathbf{P b}$ & Zn & \multirow{2}{*}{ pH } & \multirow{2}{*}{$\begin{array}{c}\mathrm{CE} \\
\mathrm{dS} / \mathrm{m}\end{array}$} & \multirow{2}{*}{$\begin{array}{c}\text { CIC } \\
\mathrm{cmol}_{\mathrm{c}} / \mathrm{kg}\end{array}$} & \multirow{2}{*}{ SAR } \\
\hline & \multicolumn{5}{|c|}{$\mathrm{mg} / \mathrm{kg}$} & & & & \\
\hline Maximum & 0096 & 1.91 & 0.31 & 1.7 & 0.88 & 10.4 & 10.3 & 16.2 & 733 \\
\hline Minimum & ND & 7.45 & 1.98 & 7.29 & 12.62 & 10.9 & 97.3 & 27.1 & 16772 \\
\hline average $^{1}$ & $0.03 \pm 0.03$ & $3.66 \pm 1.35$ & $0.51 \pm 0.36$ & $2.04 \pm 1.32$ & $2.47 \pm 2.63$ & $10.7 \pm 0.15$ & $70.9 \pm 23.42$ & $22.6 \pm 2.5$ & $4790 \pm 4119$ \\
\hline NOM-0041 ${ }^{2}$ & 39 & 1500 & 420 & 300 & 2800 & & & & \\
\hline NOM- $147^{3}$ & 37 & -- & 1600 & 400 & -- & & & & \\
\hline GPCS $^{4}$ & 0.6 & 35.7 & & 35 & 123 & & & & \\
\hline $\mathrm{NEP}^{4}$ & 3.5 & 197 & & 91.3 & 315 & & & & \\
\hline $\mathrm{NF}^{5}$ & $0.1-0.3$ & $10-25$ & 9.9 & $4-17$ & $7-38$ & & & & \\
\hline $\mathrm{CP}^{6}$ & 0.38 & 32 & 15 & 30 & 94 & & & & \\
\hline
\end{tabular}

$\mathrm{n}=19$ No. of samples.

${ }^{1}$ Average \pm deviation standard.

${ }^{2}$ Mexican Official Regulation 004-SEMARNAT-2002 (SEMARNAT, 2003).

${ }^{3}$ Mexican Official Regulation-147-SEMARNAT/SSA1-2004 (SEMARNAT, 2004).

${ }^{4}$ GPCS = Sediment quality guidelines for the protection of aquatic life (CGME, 2019a).

${ }^{5}$ Backgrownd levels for NOAA (Buchman, 2008).

${ }^{6}$ Probable concentration for 20\% toxic doses (Field et al., 2002), NOAA screening quick references Tables (Buchman, 2008).

the NOM-004-SEMARNAT-2002 (SEMARNAT, 2003). This implies that the metals have a low risk of entering the trophic chain through the absorption by plants. The concentrations are found below the maximum limits permissible of contaminated soils according to the NOM-147-SEMARNAT/SSA1-2004 (SEMARNAT, 2004) and of metals in sediments to protect the aquatic life of bodies of fresh and marine water established in the Canadian Guide and United States legislation. They are also considered from normal $(\mathrm{Cd}, \mathrm{Ni}$ and $\mathrm{Pb})$ to adequate $(\mathrm{Cu}$ and $\mathrm{Zn})$, according to the NOM-021-SEMARNAT-2000 (SEMARNAT, 2002). In reference to the values compiled by Kabata-Pendias (2011) for natural soils, the $\mathrm{Cu}$ and $\mathrm{Zn}$ concentrations from the samples are considered normal.

\section{Heavy Metals in Runoff Water}

The $\mathrm{pH}(9.7)$ is alkaline and it is not considered adequate for irrigation water (Bastian and Murray 2012). The EC present in the runoff water was $76 \mathrm{dS} \mathrm{m}^{-1}$, and exceeds the acceptable value for irrigation water in agriculture (SEMARNAT, 1997) and therefore it is not adequate for the development of crops (Ayers and Westcot, 1985), due to its high content of soluble salts (Table 2). It has been argued that the runoff water quality is of great importance, since the impermeability of the confinement (Ortiz and Gutiérrez, 2015) favors leaching and the leachate could contaminate the intermittent water courses that exist in the zone. The deposits on the margin of a tributary of the Texcoco River can have serious effects for soils downstream. 
Table 2. Water soluble metal concentrations in leachates and permissible concentrations.

\begin{tabular}{l|c|c|c|c|c}
\hline \multirow{2}{*}{} & $\mathbf{C d}$ & $\mathbf{C u}$ & $\mathbf{N i}$ & $\mathbf{P b}$ & $\mathbf{Z n}$ \\
\cline { 2 - 6 } & \multicolumn{5}{|c}{$\mathbf{~ m g / L}$} \\
\hline Average $^{1}$ & 0.01 & 0.06 & 0.09 & 0.36 & 0.13 \\
\hline $\mathrm{DE}^{2}$ & 0.009 & 0.047 & 0.086 & 0.254 & 0.044 \\
\hline
\end{tabular}

\begin{tabular}{|c|c|c|c|c|c|c|}
\hline NOM-001 ${ }^{3}$ & soils & 0.05 & 4 & 2 & 5 & 10 \\
\hline NOM-001 ${ }^{3}$ & rivers & 0.2 & 4 & 2 & 0.5 & 10 \\
\hline $\mathrm{FAO}^{4}$ & irrigation & 0.01 & 0.2 & 0.2 & 5.0 & 2.0 \\
\hline $\mathrm{EPA}^{5}$ & irrigation & 0.01 & 0.2 & 0.2 & 5.0 & 2.0 \\
\hline $\mathrm{GCA}^{6}$ & irrigation & 0.005 & $0.2-1.0$ & 0.2 & 0.2 & $1-5$ \\
\hline
\end{tabular}

${ }^{1}$ leachate sampling after rain $(\mathrm{n}=5)$, April 27, may 21, June 6 and 12 and July 2019.

${ }^{2} \mathrm{DE}$, Standard deviation.

${ }^{3}$ Mexican official regulation-001-SEMARNAT, monthly average (SEMARNAT, 1996).

${ }^{4}$ Maximum concentration in irrigation water (Ayers y Westcot, 1985).

${ }^{5}$ Maximum concentration in irrigation water (Bastian y Murray, 2012).

${ }^{6}$ Water Quality Guidelines for the Protection of Agriculture, Canada (CCME, 2019b).

Cadmium, $\mathrm{Cu}, \mathrm{Ni}, \mathrm{Pb}$ and $\mathrm{Zn}$ are lower than the maximum permissible limits of contaminants in residual water discharges in water and soil, and in its use for agricultural irrigation established in the NOM-001-SEMARNAT-1996 (SEMARNAT, 1997). Cadmium and $\mathrm{Cu}$ are within the maximum permissible limits to spill residual waters into the urban drainage systems. Likewise, the HM values are within the limits that are considered safe for the protection of agriculture established by the Food and Agriculture Organization of the United Nations (FAO; Ayers and Westcot, 1985); the Unites States Environmental Protection Agency (EPA; Bastian and Murray, 2012), and the Canadian Council of Ministers of the Environment (CGME, 2019a). Only the levels of $\mathrm{Cd}$ and $\mathrm{Pb}$ slightly exceed the safe limit (CCME, 2019b), although it should not be forgotten that concentrations in pristine water are of the order of micrograms per liter.

The low values of soluble metals determined in the runoff water are congruent with the concentrations of the sediments from the present study. Balderas et al. (2006) reported that $\mathrm{Cu}, \mathrm{Pb}$ and $\mathrm{Zn}$ from an agricultural soil near the extraction zone of the sediments of this study are adsorbed in clays and oxides, so they have low solubility, and this agrees with the reports already mentioned previously for lake sediments.

\section{Characteristics of subsoil of the Confinement}

The rock base where the sediments were deposited is the sinkhole bottom of the mine of rocky materials is a compacted and dense material, alkaline and with high EC (Table 3). According to its C.I.C. it is classified as normal, deficient and low, respectively; due to its strongly alkaline $\mathrm{pH}$, and based on EC and RAS, it is moderately saline and with high rate of sodium absorption (SEMARNAT, 2002). Likewise, it has a low organic matter content $(1.96 \%)$ and a high proportion of sand (62\%) compared to silt $(22 \%)$ and clay $(16 \%)$, which is why it is classified as loam-sandy. These characteristics make the quarry unfavorable for good plant development, so in order to rehabilitate it, corrections are required to 
Table 3. $\mathrm{pH}$, electrical conductivity (EG), cation exchange capacity (CEG), and heavy metals in the subsoil of the disposal facility.

\begin{tabular}{|c|c|c|c|c|c|c|c|c|}
\hline \multirow{2}{*}{ Concentration } & Cd & $\mathrm{Cu}$ & $\mathbf{N i}$ & $\mathrm{Pb}$ & $\mathrm{Zn}$ & \multirow[t]{2}{*}{$\mathrm{pH}$} & \multirow{2}{*}{$\begin{array}{c}\text { CE } \\
\mathrm{dS} / \mathrm{m}\end{array}$} & \multirow{2}{*}{$\begin{array}{c}\text { C.E.C. } \\
\mathrm{cmol}_{\mathrm{c}} / \mathrm{kg}\end{array}$} \\
\hline & \multicolumn{5}{|c|}{$\mathrm{mg} \mathrm{kg}^{-1}$} & & & \\
\hline Máximum & 0.02 & 0.2 & 0.23 & 0.61 & 0.49 & 10.1 & 11.9 & 2.59 \\
\hline minimum & $\mathrm{DL}$ & 0.09 & 0.13 & 0.18 & 0.22 & 9.65 & 1.21 & 1.56 \\
\hline Average & 0.02 & 0.14 & 0.16 & 0.39 & 0.35 & 9.72 & 5.16 & 1.96 \\
\hline $\mathrm{DE}^{*}$ & 0.006 & 0.081 & 0.05 & 0.21 & 0.26 & 0.31 & 5.86 & 0.54 \\
\hline
\end{tabular}

${ }^{\mathrm{a}} \mathrm{LD}=$ Below detection limit. ${ }^{\mathrm{b}} \mathrm{DE}=$ Standard desviation. $\mathrm{n}=4$ replicates.

improve its agronomic characteristics. The concentrations of HMs measured are below the maximum permissible limits of contaminated agricultural soils, according to the NOM147-SEMARNAT/SSA1-2004 (SEMARNAT, 2004).

\section{Sorption of $\mathrm{Ni}, \mathrm{Cu}, \mathrm{Pb}$ and $\mathrm{Zn}$}

The subsoil from the quarry has low permeability; however, under occasional conditions of cracking and superficial runoff, an extreme situation can be foreseen, in which the percolation water drags high concentrations of $\mathrm{HMs}$, and the possible transference to the base of the confinement and underground waters; this is why the capacity of sorption of HMs was determined in confinement materials, which could be a filtrating barrier for the transport of metals towards the aquifer.

Sorption is very high, as can be observed in the strong slopes of the isotherms at low equilibrium concentrations, to then decrease to high concentrations (L Curve, Sparks, 1995; Figure 3), which indicates a relatively high affinity of the substrate to metals at low concentrations, and decreases as the concentration increases and the specific surface of the adsorbent is saturated.

The slopes of the $\mathrm{Zn}$ and $\mathrm{Pb}$ isotherms remained high, although they decreased as the concentration increased. The slope of the $\mathrm{Cu}$ isotherm was asymptotic since its slope is high at low concentrations and then approximates zero. The slope of the isotherm of $\mathrm{Ni}$ decreased when increasing the concentration. The isotherm that best describes the behavior of $\mathrm{Zn}$ is that of Freundlich (Figure 2a), and this agrees with Cortés et al. (2015) since a good adjustment was observed to the adsorption of $\mathrm{Zn}$ in andisols, vertisols and humic acids.

In the case of $\mathrm{Cu}$ neither of the two isotherms described appropriately the tendency of the isotherm, but at high concentrations the most proximal was Langmuir's (Figure 2b), which agrees with the report from other authors who reported that the Langmuir (Abdelhamid et al., 2012) and Bourliva et al., 2015) and Redlich-Peterson isotherms provided the best adjustment for $\mathrm{Cu}$ (Han et al., 2006). The Langmuir isotherm described well the retention of $\mathrm{Pb}$ (Figure 2c). This agrees with Melichová and Hromada (2013), who found that Langmiur's isotherm explains the behavior of $\mathrm{Pb}$ and $\mathrm{Cu}$ using natural bentonite as adsorbent. Salem and Akbari-Sene (2011) obtained better adjustment with Langmuir for $\mathrm{Pb}$ in zeolite-kaolinite-bentonite adsorbent. 


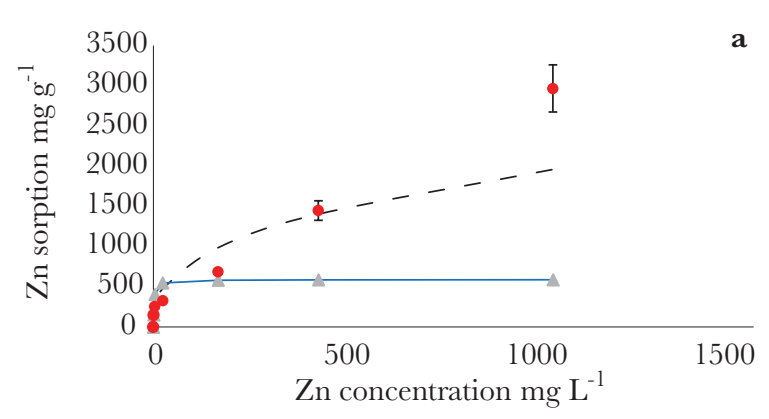

a

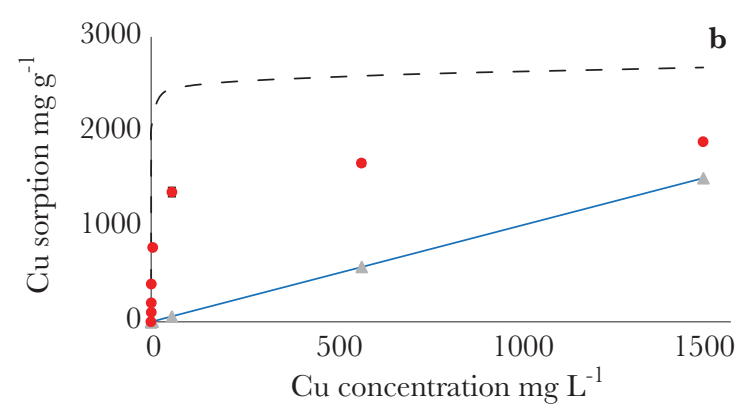

- - Freundlich $\rightarrow$ Langmuir • Experimental

- - Freundlich - - Langmuir • Experimental
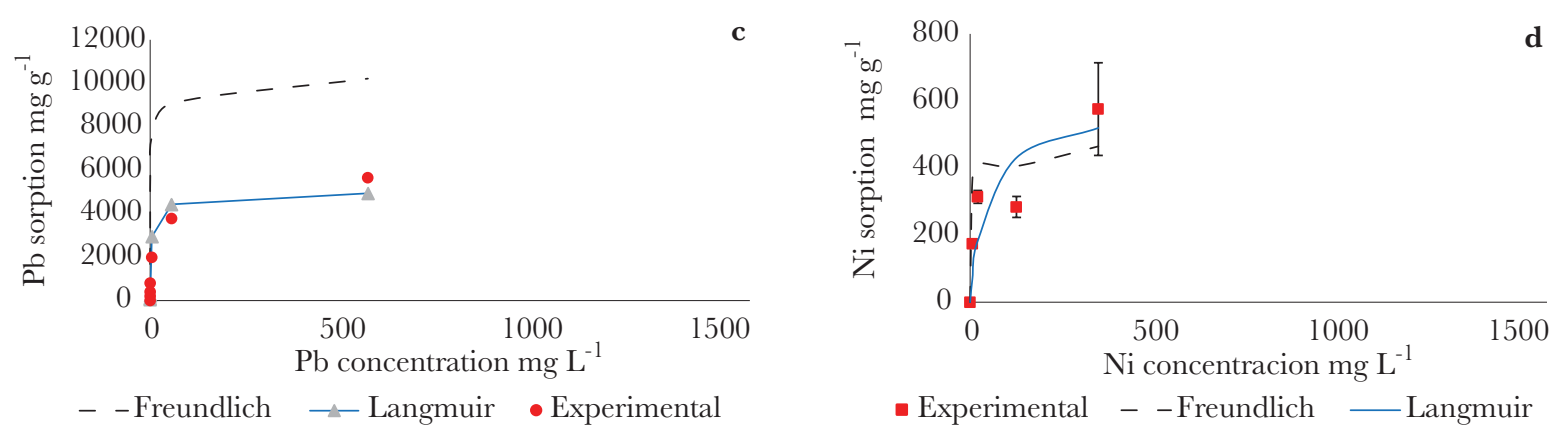

Figure 2. Experimental and simulated (using Langmuir and Freundlich equations) sorption isotherms of a) $\mathrm{Zn}, \mathrm{b}$ ) $\mathrm{Cu}, \mathrm{c}) \mathrm{Pb}$, and d) $\mathrm{Ni}$ in the subsoil of the disposal facility.

Nickel adsorption was well fit by Freundlich's equation (Figure 2d). The divergence in the sorption at intermediate concentrations can be the result of joint processes of adsorption, precipitation and change of surface in the adsorbent by the alkaline $\mathrm{pH}$ (Wang and Cheng, 2009).

When the equilibrium concentration of metals was increased, there was a decrease of the $\mathrm{pH}$ (Figure 3), which implies that chemical sorption took place (chemisorption) in the subsoil, characterized by liberation of hydronium ions (Sparks, 2003). This implies a more stable adsorption. However, Bradl (2004) mentions that the $\mathrm{pH}$ in the solution controls the sorption processes, because the hydrogen ions are constituted in an adsorbent, strongly competitive, and affected by the presence of functional groups. The sorption of cations

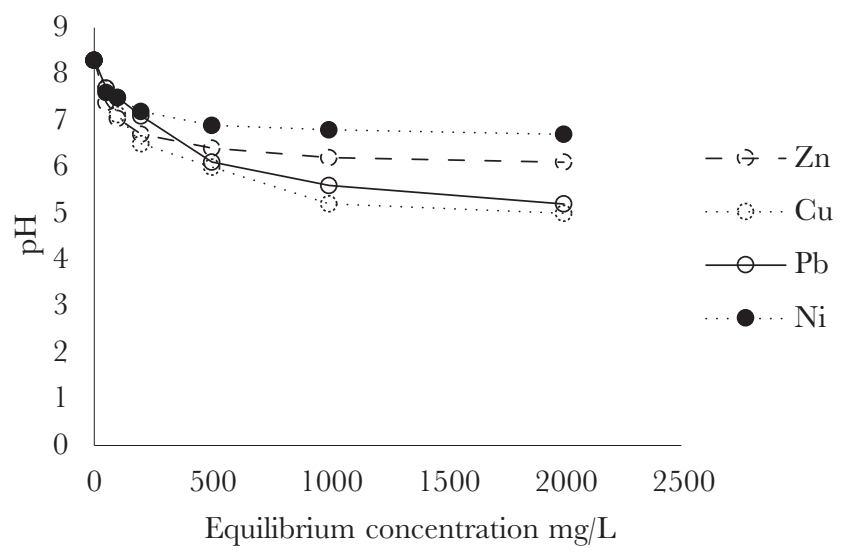

Figure 3. The $\mathrm{pH}$ at the equilibrium solution of the $\mathrm{Zn}, \mathrm{Cu}, \mathrm{Pb}$, and $\mathrm{Ni}$ isotherms. 
tends to be favored for $\mathrm{pH}$ values higher than 4.5, and the sorption of anions prefers a low value of $\mathrm{pH}$ between 1.5 and 4 (Tejeda-Tovar et al., 2015). Measuring the $\mathrm{pH}$ is important since Chaudhurib et al. (2014) mentioned that a reduction in the $\mathrm{pH}$ can unleash the transference of HMs from the adsorbent to the equilibrium solution.

Wang et al. (1997) concluded that the percentage of $\mathrm{Cu}^{2+}$ adsorbed, in most of the sediments studied, reached $100 \%$ after reaching a $\mathrm{pH}$ of 8.5 . At a high $\mathrm{pH}$ the forms of $\mathrm{Cu}$ are more stable and there is higher adsorption in the residual fraction (Balderas et al., 2006). Kaya and Ören (2005) point out a fast removal of $\mathrm{Zn}$ in the equilibrium, when the $\mathrm{pH}$ was higher than 7 and, according to Jain et al. (2004), the degree of adsorption of $\mathrm{Zn}$ increased with an increase of the $\mathrm{pH}$. Bourliva et al. (2015) point out that the adsorption of $\mathrm{Pb}, \mathrm{Cu}$ and $\mathrm{Ni}$ increases with the $\mathrm{pH}$. It is suggested that it would be necessary to break the buffer capacity of the adsorbent to reduce significantly the $\mathrm{pH}$. It is likely that the adsorption of the HMs reduces the possibilities of their lixiviation to the lower layers.

The maximum $\mathrm{Cu}, \mathrm{Pb}$, and $\mathrm{Ni}$ absorption could be estimated, since the slope tends to zero when increasing the equilibrium concentration (Table 4). The capacity for adsorption is higher than the concentration observed in the muds deposited in the confinement. A maximum in the sorption of $\mathrm{Zn}$ was not observed, for an asymptote curve was not generated in the graphic representations.

The readings of metals in the filtered supernatant were made when reaching the equilibrium, without controlling the $\mathrm{pH}$ or any other parameter as is done in some studies about adsorption (Musso et al., 2017). The $\mathrm{pH}$ of the adsorptive medium influences the behavior of the metal and its solubility, generally increasing with the rise in the concentration of hydrogen ions and influence of the intensity of the reduction-oxidation reactions (Appelo and Postma 2005). Elbana et al. (2018) reported that the soils with high content of organic matter and with alkaline $\mathrm{pH}$ show a strong adsorption for $\mathrm{Cd}, \mathrm{Cu}$, $\mathrm{Ni}, \mathrm{Pb}$ and $\mathrm{Zn}$, due to the presence of carbonate; however, in complex systems, as in the present study, it is not possible to differentiate adsorption from precipitation of insoluble forms.

\section{GONGLUSIONS}

The concentrations of $\mathrm{Cd}, \mathrm{Cu}, \mathrm{Ni}, \mathrm{Pb}$ and $\mathrm{Zn}$ from the sediment of the former Texcoco Lake confined in the quarry were within the maximum permissible limits by the Mexican laws, applicable to residual water muds for use. However, SAR, EC and $\mathrm{pH}$ are limiting factors for the development of plant species with low adaptation to salinity and alkalinity.

Table 4. $\mathrm{Zn}, \mathrm{Cu}, \mathrm{Pb}$, and $\mathrm{Ni}$ adsorption fitting parameters to the Langmuir and Freundlich equations on the subsoil of the quarry.

\begin{tabular}{|c|c|c|c|c|c|c|c|c|}
\hline \multirow{2}{*}{ Metal } & \multicolumn{3}{|c|}{ Langmuir } & \multirow[b]{2}{*}{ SqMin. } & \multicolumn{3}{|c|}{ Freundlich } & \multirow{2}{*}{ SqMin } \\
\hline & $\mathbf{M}(\mathrm{mg} / \mathrm{g})$ & $\mathrm{K}_{\mathrm{L}}(\mathrm{L} / \mathbf{m g})$ & $\mathbf{R}^{2}$ & & $\mathbf{K}_{\mathrm{F}}(\mathrm{mg} / \mathrm{L} / \mathrm{g})$ & $1 / n$ & $\mathbf{R}^{2}$ & \\
\hline $\mathrm{Zn}$ & 588 & 0.54 & 0.76 & 6.48 & 141.3 & 0.37 & 0.92 & 1.13 \\
\hline $\mathrm{Cu}$ & 2000 & 0.07 & 0.99 & 3.87 & 354.6 & 0.26 & 0.89 & 8.56 \\
\hline $\mathrm{Pb}$ & 5000 & 0.133 & 0.99 & 2.28 & 808.5 & 0.29 & 0.93 & 13.51 \\
\hline $\mathrm{Ni}$ & 580 & 0.021 & 0.88 & 0.05 & 137 & 0.191 & 0.452 & 0.07 \\
\hline
\end{tabular}

SqMin. Square minimums $\times 10^{6}$. 
The concentrations of HMs in the runoff water are within the acceptable limits established by the Mexican laws for the discharge of waters into rivers and the soil for irrigation; they are also within the safe limits for irrigation proposed by FAO and EPA. However, the pH and EC would limit their use in irrigation. Considering Freundlich and Langmuir's adsorption isotherms, the material from the subsoil of the confinement sorbs metals following the decreasing affinity order: $\mathrm{Pb}>\mathrm{Zn}>\mathrm{Cu}$. The capacity for adsorption of $\mathrm{Pb}, \mathrm{Zn}, \mathrm{Cu}$ and $\mathrm{Ni}$ in the materials from the bottom is higher than its concentration in the runoff water.

The materials from the bottom present low $\mathrm{Cd}, \mathrm{Cu}, \mathrm{Ni}, \mathrm{Pb}$, and $\mathrm{Zn}$ concentrations, poor fertility and high $\mathrm{pH}$ values. These last characteristics anticipate their low capacity to support wild vegetation or cultivated normally. However, there is still the need to evaluate the capacity to liberate the metals adsorbed, desorption, which could be increased if the $\mathrm{pH}$ or the content of salts varies in the system.

\section{REFERENGES}

Abdelhamid B., Ourari A. and Ouali M.S. (2012). Copper (II) ions removal from aqueous solution using bentonite treated with ammonium chloride. American Journal of Physical Chemistry 1(1), 1-10. DOI: $10.11648 / \mathrm{j}$. ajpc.20120101.11

Anónimo, (2014). Revisión y evaluación en geotecnia y estructuras para resolver la problemática del transporte aéreo en el centro del país. Convenio de colaboración N0 ASA-UNAM-1-002. 5. Avance de los estudios específicos. Geotecnia. UNAM. https://lopezobrador.org.mx/wp-content/uploads/2018/08/3Geologia-general-de-la-zona.pdf.

Appelo C.A.J. and Postma D. (2005). Geochemistry groundwater and pollution. 2nd edition. A. A. Balkema Publishers. Amsterdam, Netherlands. 1-683 pp. DOI:10.1201/9781439833544

Ayers R.S. and Westcot D.W. (1985). Water quality for agriculture. FAO Irrigation and Drainage Paper 29 Rev. 1. Food and Agriculture Organization of the United Nations. Roma, Italia. 174 pp.

Balderas P.M.A., Gutiérrez G.M.G., Carrillo G.R., Ortiz S.G.A., y Lugo de la Fuente J.A. (2006) Distribución de elementos traza en los suelos de las microcuencas en Texcoco. Terra Latinoamericana 24 (4), 451-461.

Bastian R. and Murray D. (2012). Guidelines for Water Reuse. U.S. Environmental Protection Agency, Washington, D.C. EPA/600/R-12/618. 643 pp. [en línea]. https://www3.epa.gov/region1/npdes/ merrimackstation/pdfs/ar/AR-1530.pdf 05/03/2019

Bradl H.B. (2004). Adsorption of heavy metals ions on soils and soils constituents. Journal of Colloid and Interface Science 277 (1), 1-18. DOI: 10.1016/j.jcis.2004.04.005

Bourliva A., Michailidis K., Sikalidis C., Filippidis A., and Betsiou M. (2015). Adsorption of Cd (II), Cu (II), Ni (II) and $\mathrm{Pb}$ (II) onto natural bentonite: study in mono- and multi-metal systems. Environmental Earth Sciences. 73(9), 5435-5445. DOI: 10.1007/s12665-014-3798-0

Buchman M.F. (2008). NOAA Screening Quick Reference Tables. NOAA OR\&R Report 08-1., Office of Response and Restoration Division, National Oceanic and Atmospheric Administration. Seattle, E.U.A. 34 pp. [en línea]. https://repository.library.noaa.gov/view/noaa/9327 04/03/2019

Carranza E.A. (2018). Correlación litológica del subsuelo del lago de Texcoco. Hidrobiológica 28 (1), 93-101. DOI: 10.24275/uam/izt/dcbs/hidro/2018v28n1/Carranza

GCME (2019a). Sediment Quality Guidelines for the Protection of Aquatic Life. Canadian Council of Ministers of the Environment. Canadá, 4 pp. [en línea]. http://st-ts.ccme.ca/en/index.html 04/03/2019

CGME (2019b). Water Quality Guidelines for the Protection of Agriculture. Canadian Council of Ministers of the Environment. Canada, 9 pp. [en línea]. http://st-ts.ccme.ca/en/index.html 04/03/2019

Chaudhurib T.R., Fazlic P., Zamana S., Pramanickd P., Bosea R. and Mitraa (2014) Impact of acidification on heavy metal pollution in Hooghly estuary. Journal of Harmonized Research in Applied Sciences 2(2), 91-97.

Cortés P.L.E., Bravo R.I.S., Martín P.F.J., and Menjivar F.J.C. (2015). Adsorción de metales pesados en andisoles, vertisoles y ácidos húmicos. Acta Agronómica 64 (1), 61-71. DOI: 10.15446/acag.v64n1.43677

Elbana T.A., Selim H.M., Akrami N., Newman A., Shaheen S.M., and Rinklebe J. (2018). Freundlich sorption parameters for cadmium, copper, nickel, lead, and zinc for different soils: Influence of kinetics. Geoderma 324, 80-88. DOI:10.1016/j.geoderma.2018.03.019 
Field L.J., MacDonald D.M., Norton S.B., Ingersoll C.G., Severn G.G., Smorong D., and Lindskoog R. (2002). Predicting amphipod toxicity from sediment chemistry using logistic regression models. Environmental Toxicology and Chemistry 21(9), 1993-2005. DOI: 10.1002/etc.5620210929

GACM (2014). Manifestación de Impacto Ambiental Modalidad Regional del Nuevo Aeropuerto Internacional de la Ciudad de México. Resumen Ejecutivo Grupo Aeroportuario de la Ciudad de México, S.A. de C.V. México. 22 pp. [en línea]. https://apps1.semarnat.gob.mx:445/dgiraDocs/documentos/mex/ resumenes/2014/15EM2014V0044.pdf 5/03/2019

Green J. A., Pavlish J. A. Merritt R. G., and Leete J. L. (2005). Hydraulic impact of quarries and gravel pits. Minnesota Environment and Natural Resources Trust Fund. pp. 35.

Han R., Lu Z., Zou W., Daotong W., Shi J. and Jiujun Y. (2006). Removal of copper (II) and lead (II) from aqueous solution by manganese oxide coated sand: II. Equilibrium study and competitive adsorption. Journal of Hazardous Materials 137(1), 480-488. DOI: 10.1016/j.jhazmat.2006.02.018

Hazelton P. y B. Murphy. (2007). Interpreting soil test results. What do all the numbers mean? CSIIRO. Publishing. Australia.

Jain G.K., Singhal D.C. and Sharma M.K. (2004). Adsorption of zinc on bed sediment of River Hindon: adsorption models and kinetics. Journal of Hazardous Materials 114(1-3), 231-239. DOI: 10.1016/j. jhazmat.2004.09.001

Kabata-Pendias A. (2011). Trace elements in soils and plants. $4^{\text {th }}$ ed. Taylor and Francis Group. New York, U.S.A. 505 pp.

Kaya A. and Ören A. H. (2005). Adsorption of zinc from aqueous solutions to bentonite. Journal of Hazardous Materials 125 (1-3), 183-189. DOI: 10.1016/j.jhazmat.2005.05.027

Korkmaz H., Cetin B., Ege I., Karatas A., Bom A., and Ozsahin E. (2001). Environmental effects of Stone pits in Hatay (Turkey). Procedia Social and Behavioral Sciences 19, 504-510

López A.N.P., Espinosa S.A.L. and Zuluaga B.D. (2016). Sobre la permeabilidad del subsuelo en la zona del ex Lago de Texcoco. Memoria de la XXVIII Reunión Nacional de Ingeniería Geotécnica. Mérida Yucatán. 23-26 de noviembre de 2016.

Luo M., Li J., Cao W. and Wang M. (2008). Study of heavy metals speciation in branch sediments of Poyang Lake. Journal Environmental Sciences 20 (2), 161-166. DOI: 10.1016/S1001-0742(08)60025-X

Melichová Z. and Hromada L. (2013). Adsorption of $\mathrm{Pb}^{2+}$ and $\mathrm{Cu}^{2+}$ ions from aqueous solutions on natural bentonite. Pol. J. Environ. Stud. 22 (2), 457-464.

Morales-García S.S. Meza-Olvera E., Shruti V.C., Sedeño-DíazJ.E., (2020). Assessment of metal contamination and their ecological risks in wetland sediments of the former Texcoco saline lake, México. Journal Soil Sediments 20, 2912-2930.

Morton-Bermea O., Hernández-Álvarez E., González-Hernández G., Romero F., Lozano R. and BeramendiOrosco L.E. (2009). Assessment of heavy metal pollution in urban topsoils from the metropolitan area of Mexico City, Journal of Geochemical Exploration 101 (3), 218-224. DOI: 10.1016/j. gexplo.2008.07.002

Musso T.B., Pettinari G., Parolo M.E. and Mesquín L. (2017). Arcillas esmectíticas de la región Norpatagónica Argentina como barreras hidráulicas de rellenos sanitarios y agentes de retención de metales pesados. Revista Internacional de Contaminación Ambiental 33 (1), 141-152. DOI: 10.20937/ RICA.2017.33.01.13

Ortiz S.C.A. and Gutiérrez C.M. del C. (2015). El Nuevo Aeropuerto Internacional de la Ciudad de México: Las limitaciones de los terrenos del ex lago de Texcoco. Artículos y Ensayos de Sociología Rural 10 (19). 11-23.

Pejman A., Bidhendi G. N., Ardestani M., Saeedi M. and Baghvand A. (2015). A new index for assessing heavy metals contamination in sediments: a case study. Ecological Indicators 58, 365-373. DOI: 10.1016/j. ecolind.2015.06.012

QGIS Development Team (2009). QGIS Geographic Information System. Open Source Geospatial Foundation. [en línea]. https://qgis.org/es/site/ 06/03/2019

Roy W., Krapac I., Chou S. and Griffin R. (1992). Batch-type procedures for estimating soil adsorption of chemicals. U.S. Environmental Protection Agency, Washington, D.C., EPA/530/SW-87/006F. 116 pp. [en línea]. https://nepis.epa.gov/Exe/ZyPDF.cgi/100018S4.PDF?Dockey=100018S4.PDF $5 / 03 / 2019$

Rowell, D.L., 1994. Soil Science: Methods and Applications. Longman Scientific \& Technical/John Wiley \& Sons.

Salem A. and Akbari-Sene R. (2011). Removal of lead from solution by combination of natural zeolite-kaolinbentonite as a new low-cost adsorbent. Chemical Engineering Journal. 174 (2-3), 619-628. DOI: 10.1016/j.cej.2011.09.075 
SE (2016a). Norma Mexicana NMX-AA-051-SCFI-2016. Análisis de agua. Medición de metales por absorción atómica en aguas naturales, potables, residuales y residuales tratadas. Método de prueba. Secretaría de Economía. Diario Oficial de la Federación. 3 de noviembre de 2016.

SE (2017). Norma Mexicana NMX-AA-132-SCFI-2006. Muestreo de suelos para la identificación y la cuantificación de metales y metaloides, y manejo de la muestra. Secretaría de Economía. Diario Oficial de la Federación. 06 de marzo de 2017.

SECOFI (1980). Norma Mexicana NMX-AA-003-1998. Aguas residuales. Muestreo. Secretaría de Comercio y Fomento Industrial. Diario Oficial de la Federación. 6 de noviembre de 1992.

Segura G.M.A., Gutiérrez C.M. del C., Ortiz S.C.A., and Gómez D.D.J. (2000). Suelos arcillosos de la zona oriente del Estado de México. Terra Latinoamericana 18 (1). 35-44.

SEMARNAT (1997). Norma Oficial Mexicana NOM-001-SEMARNAT-1996. Límites máximos permisibles de contaminantes en las descargas de aguas residuales en aguas y bienes nacionales. Secretaría de Medio Ambiente y Recursos Naturales. Diario Oficial de la Federación. 23 de abril de 2003.

SEMARNAT (2002). Norma Oficial Mexicana NOM-021-SEMARNAT-2000. Especificaciones de fertilidad, salinidad y clasificación de suelos. Estudios, muestreo y análisis. Secretaría de Medio Ambiente y Recursos Naturales. Diario Oficial de la Federación. 31 de diciembre de 2002.

SEMARNAT (2003). Norma Oficial Mexicana NOM-004-SEMARNAT-2002. Lodos y biosólidos. Especificaciones y límites máximos permisibles de contaminantes para su aprovechamiento y disposición final. Secretaría de Medio Ambiente y Recursos Naturales. Diario Oficial de la Federación. 15 de agosto de 2003.

SEMARNAT (2004). Norma Oficial Mexicana NOM-147-SEMARNAT/SSA1-2004. Criterios para determinar las concentraciones de remediación de suelos contaminados por arsénico, bario, berilio, cadmio, cromo hexavalente, mercurio, níquel, plata, plomo, selenio, talio y/o vanadio. Secretaría de Medio Ambiente y Recursos Naturales. Diario Oficial de la Federación. 2 de marzo de 2007.

SGM (2002). Carta geológico-minera 1:250,000. E14-2. Ciudad de México. Servicio Geológico Minero. [en línea]. http://mapserver.sgm.gob.mx/Cartas_Online/geologia/89_E14-2_GM.pdf 06/03/2019

Siltecho S., Hammecker C., Sriboonlue V., Clermont-Dauphin C., Trelo-Ges V., Antonino A.C.D. and Angulo-Jaramillo R. (2015). Use of field and laboratory methods for estimating unsaturated hydraulic properties under different land uses, Hydrol. Earth Syst. Sci. 19, 1193-1207. DOI: 10.5194/hess-191193-2015

Sobczynski T. and Siepak J. (2001). Speciation of heavy metals in botton sediments of lakes in the area of Wielkopolske National Park. Polish Journal of Environmental Studies 10(6), 463-474.

Sparks D.L. (2003). Environmental soil chemistry. 2a ed. Elsevier. San Diego, California, U.S.A. 352 pp.

Tarín V. M. and Velázquez L.A. (1986). Lavado de suelos en el ex-Lago de Texcoco. Ingeniería Hidráulica en México. Mayo-Agosto: 30-49 pp.

Tejeda-Tovar G., Villabona-Ortiz A., and Garcés-Jaraba L. (2015). Adsorción de metales pesados en aguas residuales usando materiales de origen biológico. Tecno Lógicas 18 (34), 109-123.

Van der Perk M. (2013). Soil and water contamination. $2^{\text {nd }}$ ed. CRC Press. Balkema. Netherlands. 428 pp.

Vowotor M.K., Hood C.O., Sackey S.S., Owusu A., Tatchie E., Nyarko S., Osel D.M., Mireku K.K., Letsa C.B. and Atleomo S.M. (2014). An assessment of heavy metal pollution in sediments of a tropical lagoon: A case study of the Benya Lagoon, Komenda Edina Eguafo Abrem Municipality (KEEA) Ghana. Journal of Health and Pollution 4(6), 26-39. DOI: 10.5696/2156-9614-4-6.26

Wang J.L. and Chen C. (2009). Biosorbents for heavy metals removal and their future. Biotechnology Advances 27 (2), 195-226. DOI: 10.1016/j.biotechadv.2008.11.002

Wang F.Y., Chen J.S. and Forsling W. (1997). Modeling sorption of trace metals on natural sediments by surface complexation model. Env. Sci. Technol. 31 (2), 448-453. DOI: 10.1021/es960270a

Wu B., Wang G., Wu J., Fu Q. and Liu C. (2014). Sources of heavy metals in surface sediments and an ecological risk assessment from two adjacent Plateau reservoirs. PloS one 9 (7). DOI: 10.1371/journal. pone.0102101 